\title{
Real Exchange Rate Misalignment in Saudi Arabia
}

\author{
Emad Omar Elhendawy \\ Correspondence: Emad Omar Elhendawy, Qassim University, College of Business \& Economics, Economic and \\ finance Department, Saudi Arabia. Cairo. Tel: 20-55-376-5504/20-11-1835-8906. E-mail: \\ emad_elhendawy_2006@hotmail.com
}

Received: September 26, 2012

Accepted: October 18, $2012 \quad$ Online Published: November 3, 2012

doi:10.5539/ijef.v4n12p98

URL: http://dx.doi.org/10.5539/ijef.v4n12p98

\begin{abstract}
This paper attempts to measure degree of misalignment of the Saudi Riyal by estimating the long run equilibrium real exchange rate of the currency. Based on cointegration technique, this paper has identified, government consumption expenditure, GDP growth and gross capital formation as important determinants of the Saudi Riyal long run equilibrium value. Results suggest that the actual real exchange rate was below the estimated equilibrium (Saudi Riyal over valued) in 1980,198 1 and 1982 by $25 \%, 16 \%$ and $7 \%$ respectively. Following 1983, the Saudi real exchange rate rose above the equilibrium exchange rate thus starting an era of undervaluation of the Saudi currency that lasted until the year 2009. The downward slide began in 1983 when the riyal fell below its equilibrium exchange rate by $1 \%$ with the declining trend deteriorating further to $10 \%$ in 1984 , $19 \%$ percent in $1985,27 \%$ in 1986 and so on until it hit an all-time low of 84 percent below estimated equilibrium in 2006. Thereafter, the decline started receding gradually with the misalignment below exchange rate equilibrium improving to about 80 percent in 2009.
\end{abstract}

Keywords: equilibrium real exchange rate, misalignment, cointegration tests, Hodrick and Prescott Filter, Saudi Arabia

\section{Introduction}

Economists have paid considerable attention to measuring real exchange rate misalignment in many developed as well as less developed countries (Rogoff, 1996). This paper focuses on the Saudi Arabian case. Saudi Arabia has a long history of following a fixed exchange rate system aimed at stabilizing the foreign sector which is the backbone of the Saudi economy. Such a policy would naturally drive a wedge between the actual and equilibrium real exchange rate which could in turn adversely affect the economy in a number of ways. For example, economists have pointed out that misalignment between actual and equilibrium exchange rate could result in a misallocation of resources, reduced welfare and growth rates, distorted relative prices of tradable to non tradable goods and even destabilizing the economy. This research therefore seeks to identify the major factors that underlie the determination of the equilibrium real exchange rate in the Saudi economy as well as measuring the extent of misalignment between actual and equilibrium real exchange rates in that economy.

Thus the study looks into the equilibrium exchange rate time path and the misalignment between the actual and equilibrium exchange rate in Saudi Arabia for the period 1980-2009. A model of exchange rate behavior will be developed in which we partially follow the lead of such authors as Edwards (1987) and Elbadawi (1994) who advocated some fundamental determinants of the equilibrium real exchange rate. The rest of this paper is organized as follows; section 2 briefly outlines the concept of real exchange rate misalignment. Section 3 presents the methodology and model estimation. Section 4 presents the results and discussion while section 5 concludes the research.

\section{Real Exchange Rate Misalignment}

A misalignment is said to take place when the RER goes astray from the standpoint of factors governing its behavior for a considerable period of time (Edwards, 1987). The misalignment could be measured by the spread between the observed RER and the equilibrium RER which is, of course, non-observed. When the value of RER exceeds its equilibrium value, RER is said to be "overvalued" and vice versa. Misalignment can take place in a couple of ways. Firstly, economic policy may at times be out of line with the adopted exchange rate regime which may lead to a departure of RER from its equilibrium value. This is referred to as the macroeconomic- induced misalignment. 
For example an over-expansion in monetary policy may cause the price of domestic goods to rise faster than world prices. This will, other things remaining equal, cause RER to appreciate as international reserves start to dwindle. Secondly, in some cases, the major factors influencing the equilibrium RER may change but the changes don't get reflected on the actual RER immediately or within a reasonably short period of time. For example a deterioration in a country's terms of trade will most likely result in a higher equilibrium RER other things remaining the same. If the actual RER doesn't rise in line with the equilibrium RER, misalignments will take place. The major factors influencing RER are subject to numerous types of changes that may lead to significant disparities between the actual and equilibrium RER. In order to gauge some measure of the misalignment, we use the single-equation approach. Thus a single-equation model will be estimated using historical time series data and panel co integration techniques. Following that, we compute the long run values of the major RER determinants using the Hodrick and Prescott filter(HP) (Note 1). We then use these long run values to calculate the equilibrium RER. Misalignments are simply calculated as the spread between the actual and equilibrium RER.

\section{Real Exchange Rate Misalignments Estimation}

The estimation of the real exchange rate is a crucial step that must underlie any serious study aimed at measuring RER misalignments. In this respect, we employ here an empirical definition which is a variant of the ppp theory that was the subject of considerable debate. One approach in international finance theory sees RER series as permanently affected by shocks and advocates the view that the equilibrium real exchange rate is subject to shifts over time. The upshot of this line of thought is to discard the idea that ppp oscillates to a stable long run mean level (Cristina and Valladares 2003). The exchange rate is nevertheless assumed to converge to some long run stable level, but not the ppp. Instead, other arguments, dubbed fundamentals, are incorporated into the determination of RER and a long run equilibrium relationship sought among the relevant variables. Basically, this approach estimates a co integrating relation between RER time series and several relevant "fundamentals" influencing RER. It is tacitly assumed that RER is made up of two constituents; a non- stationary I (1) series, and another constituent with a stationary behavior I (0). The former constituent represents permanent changes in RER while the latter represents transitory changes that tend to disappear over time.

\subsection{Methodology and Model Estimation}

As alluded to above, a well-known approach (Engel et al, 2007) to exchange rate determination is the behavioral equilibrium exchange rate (BEER) approach. To determine the misalignment of the exchange rate, this approach utilizes econometric tools to estimate the equilibrium exchange rate and then compares the results to the actual exchange rate. In the process BEER estimates a reduced form equation which includes key arguments that affect real exchange rate. In this paper, we use a methodology which utilizes unit root and co integration tests (Baffes, Elbadawi and O'Connell,1997). At the outset, we test a unit root in various series, after which we test for co integration between the real exchange rate and what are presumably its major influential factors (fundamentals). At length, the long-run parameters are estimated. The latter are to be used in computing real equilibrium exchange rate and the extent of misalignments. The functional relationship between the real exchange rate and its explanatory variables may be posited by the following equation:

$$
\text { In RER } t=a+B_{1} \text { In NFA } t+B_{2} \text { In GOV } t+B_{3} G D P t+B_{4} \text { In Capital } t+u t
$$

The variables are defined as follows:

$\mathrm{RER}_{\mathrm{t}}=$ real exchange rate (Note 2 )

$\mathrm{NFA}_{\mathrm{t}}=$ net foreign assets LCU billion

$\mathrm{GOV}_{\mathrm{t}}=$ general government final consumption expenditure GDP\%

GDP $_{\mathrm{t}}=$ GDP growth annual \%

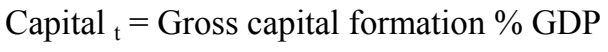

$\mathrm{U}_{\mathrm{t}}=$ White-noise error term (Note 3)

It is imperative to delineate the variables influencing RER in order to estimate misalignments. The extent of such misalignments can be gauged by calculating the spread between the actual and the equilibrium RER. But the calculation of RER is not quite a simple matter. Thus Arberola (2003) notes that an estimate of the equilibrium rate is obtainable from a co integration relationship between the RER and its determinants only if the equilibrium level of the determinants could be observed. This implies that calculating long run equilibrium RER involves the prior determination of the long- run values of the arguments influencing it.

This could be done in several ways. Here, we opt for using the Hodrick and Prescott (HP) approach (1997) to work 
out the long run values of the RER determinants.

These long run values are then plugged into the estimated model to calculate the equilibrium RER. Lastly, normalizing equilibrium RER would set misalignment equal to zero in the long-run.

To obtain the size of RER misalignment at any point in time, we calculate the spread between actual RER and its long- run equilibrium value which amounts to computing the following equation:

$$
M I S=\frac{E R E R-R E R}{E R E R}
$$

ERER denotes the long-run equilibrium value of RER derived from equation (2).The Saudi riyal is said to be over (under) valued according as MIS is positive (negative)

\subsection{Data}

The study sample in the present research consists of a time- series that covers the period 1980 through 2009. The data were obtained from the World Bank Indicators (WDI) of 2011. Four explanatory variables have been postulated as the long-run structural factors which influence changes in Saudi RER (Aleisa and Dibooghe, 2002): government size, Net foreign assets, GDP growth and capital formation. Below is a discussion of how these basic factors impact on RER and the nature of the variables used as proxies for these factors.

\section{A. Net foreign Assets (NFA)}

A positive net asset holding usually boosts a country's capacity to import. It also increases demand for domestically produced goods (both tradables and nontradables) and their prices which may result in an exchange rate appreciation.

\section{B. Size of government (GDP)}

In many cases, an expansion of government expenditure shifts domestic demand from trdables to nontradables and thus impact RER.For example whenever increases in government. Expenditures are directed more heavily towards nontradables compared to private spending, RER will likely appreciate in the wake of an increase in governmental expenditure.

In this respect, a possible scenario within the context of oil producing countries is that increases in oil prices may likely produce significant increases in government expenditure. If the increase in government expenditure impinges more heavily on nontradables, a not implausible assumption, their prices will rise thus causing an appreciation of RER. This scenario is particularly plausible in oil producing countries such as Saudi Arabia because the government is in most cases the sponsor for large construction project executed by the private sector. Expenditures on such projects are usually tilted towards nontradables.

\section{Technological Improvement (measured in terms of real GDP growth)}

Technological progress naturally reflects positively on the economy in many ways. It may lead to increased productivity for the factors of production, enhanced and more effective managerial processes as well as reduced costs and lower prices for domestic products particularly tradables. If the costs of tradables and their prices fall, this will lead to an exchange rate depreciation. However, if technological progress raises income and demand for nontradables but causes a reduction in the relative prices of tradables to nontradables, RER will go up (Mamta, 1999).

\section{Capital accumulation}

Capital is a crucial factor to the economic growth and technological progress of a country. Whether capital accumulation can significantly influence changes in the exchange rate depends on where the accumulation originates. For example if the capital accumulation takes place mostly in the export sector, its impact will be different than if it originates in the import substitutes and nontradables (Aftidi, 1995). The income elasticities of the industries involved are also relevant. But in the final analysis, the effects of capital accumulation on the exchange rate cannot be determined apriori.

\subsection{Unit Root and Co Integration Tests}

Before embarking on the use of the time-series method, it is appropriate to test for the unit root. A tacit assumption in time series regression is that the relevant variable series are stationary. By this is meant that the mean variances and auto-co variances do not change over time. Consequently, we follow the standard procedure of unit root testing by employing the Augmented Dickey Fuller (ADF). Table (1) presents the results of the stationary test. 
Table 1. Summary of ADF Unit Root Test Result

\begin{tabular}{|c|c|c|c|c|c|c|}
\hline \multicolumn{7}{|c|}{ Augmented Dickey Fuller (ADF) Test } \\
\hline \multirow[t]{2}{*}{ Variables } & \multicolumn{3}{|c|}{ Constant } & \multicolumn{3}{|c|}{ Trend } \\
\hline & Level & First-Difference & Conclusion & Level & First- Difference & Conclusion \\
\hline Ln RER & -1.91 & -5.17 & $\mathrm{I}(1)$ & -2.931 & 3.21 & \\
\hline $\ln \mathrm{NFA}$ & $-3.71 * *$ & -1.75 & $\mathrm{I}(0)$ & -2.89 & -0.83 & \\
\hline $\ln \mathrm{GOV}$ & 0.30 & $-3.22 * *$ & $\mathrm{I}(1)$ & $-4.33 * *$ & $-11.14^{* *}$ & $\mathrm{I}(0)$ \\
\hline GDP & $-7.17 * * *$ & -2.29 & $\mathrm{I}(0)$ & -1.47 & -2.82 & \\
\hline Ln Capital & -0.57 & 0.088 & & 2.16 & $-3.27 *$ & $\mathrm{I}(1)$ \\
\hline
\end{tabular}

at Notes: 1) For ADF and PP tests, ***,** and * denote rejection of a unit root hypothesis based on Mackinnon (1991) critical values at $10 \%, 5 \%$ and $1 \%$ respectively

The results of table (1) show that variables such as real exchange rate, government expenditure and gross capital formation are stationary at first difference, but that net foreign assets and GDP growth are stationary at levels. By and large, the variables are integrated of order one, a fact which signifies that the estimated equations can from a long-run relationship of the real exchange rate (Zakaria, 2010). Next, we utilize the co integration technique to test for long- run relationships. In the literature of co integrated time series, an individually non - stationary variable at level becomes stationary when combined together through linear combinations with other variables; It follows from this result that a time varying model of the exchange rate can be constructed which poses RER as a function of an array of explanatory variables. As alluded to above, the present study uses co integration analysis to find out whether there is a long run equilibrium relationship linking the real exchange rate to a number of variables which presumably have important influences on the exchange rate. With such a relationship firmly in place, we next proceed to estimate the vector error correction model.

In order to ensure that the co integrating vectors estimators garner a high level of efficiency, we opt for using VECM, which is a variant of full information maximum likelihood models. (Sidek and Yusoff, 2009) Opting for VECM offers several advantages. For one thing this procedure carries the possibility of testing for co integration in one step and with no normalization for any of the variables. For another, it doesn't require the endogeniety or exogeniety assumptions of the variables. The moral of VECM is that it drives the endogenous variables towards their long run stable values without undermining short term adjustment dynamics. Table (2) below reports the results of Johansen cointegration test for five equations at the 5\% and $1 \%$ levels for Trace Max- eigenvalue tests.

Table 2. Summary of Johansen Cointegration Test

\begin{tabular}{|c|c|c|c|c|}
\hline \multicolumn{5}{|c|}{ Unrestricted Cointegration Rank Test } \\
\hline Hypothesized & Eigenvalue & Trace & 5 Percent & 1 Percent \\
\hline No. of $\mathrm{CE}(\mathrm{s})$ & & Statistic & Critical Value & Critical Value \\
\hline None $* *$ & 0.99 & 391.69 & 68.52 & 76.07 \\
\hline At most $1 * *$ & 0.97 & 216.31 & 47.21 & 54.46 \\
\hline At most $2 * *$ & 0.90 & 111.79 & 29.68 & 35.65 \\
\hline At most $3 * *$ & 0.72 & 46.41 & 15.41 & 20.04 \\
\hline At most $4 * *$ & 0.31 & 10.50 & 3.76 & 6.65 \\
\hline \multicolumn{5}{|c|}{$*(* *)$ denotes rejection of the hypothesis at the $5 \%(1 \%)$ level } \\
\hline \multicolumn{5}{|c|}{ Trace test indicates 5 cointegrating equation(s) at both $5 \%$ and $1 \%$ levels } \\
\hline Hypothesized & Eigenvalue & Max-Eigen & 5 Percent & 1 Percent \\
\hline No. of $\mathrm{CE}(\mathrm{s})$ & & Statistic & Critical Value & Critical Value \\
\hline None $* *$ & 0.99 & 175.37 & 33.46 & 38.77 \\
\hline At most $1 * *$ & 0.97 & 104.51 & 27.07 & 32.24 \\
\hline At most $2 * *$ & 0.90 & 65.38 & 20.97 & 25.52 \\
\hline At most $3 * *$ & 0.72 & 35.90 & 14.07 & 18.63 \\
\hline At most $4 * *$ & 0.31 & 10.50 & 3.76 & 6.65 \\
\hline \multicolumn{5}{|c|}{$*(* *)$ denotes rejection of the hypothesis at the $5 \%(1 \%)$ level } \\
\hline
\end{tabular}

\section{Results}

\subsection{Estimated Saudi Equilibrium RER}

Estimates of the long run relationship between the Saudi RER and its determinants are given in equation (2) below: 


$$
\begin{aligned}
& \text { In } R_{E R} R_{t-1}=-2.952-0.09 \text { In NFA }_{t-1}-0.44 \text { In Gov }_{t-1} \\
& +0.054 \text { GDP }_{t-1}+1.247 \text { In Capital }_{t-1}
\end{aligned}
$$

The estimates are also provided in table (3). Presumably, long run changes in the postulated explanatory variables will work to eliminate any disparities from the equilibrium co integrating relationship, a tendency which is confirmed by the significant error correction term (see table 3 ).

Table 3. Summary of over parameterized ECM Result

\begin{tabular}{lccc}
\hline \multicolumn{1}{c}{ variable } & coefficient & Std. Error & t-Statistic \\
\hline \multicolumn{1}{c}{ LN NFA (-1) } & -0.09 & 0.03101 & -2.92 \\
LN GOV(-1) & -0.44 & 0.056 & -7.87 \\
GDP(-1) & 0.054 & 0.010 & 5.36 \\
LN CAPITAL(-1) & 1.247 & 0.206 & 6.03 \\
C & -2.952 & & \\
Error Correction & -0.01 & 0.00515 & -2.19 \\
D(LN RER (-1) & 1.63 & 0.44563 & 3.66 \\
D(LN RER (-2) & -0.75 & 0.29547 & -2.54 \\
D(LN GOV(-1) & 0.097 & 0.03904 & 2.49 \\
\hline R-squared & 0.99 & Akaike Information & -58.41 \\
Adj. R-quared & 0.99 & Criteria & \\
Log likelihood & 230.32 & Schwarz Criteria & -55.291 \\
& \multicolumn{3}{c}{ F-statistic } \\
\hline
\end{tabular}

These findings corroborate to the strong influence imparted by the explanatory variables on the changes in Saudi REER in the long run. The coefficients of the variables are significant and their signs are consistent with what is predicted by economic theory. Thus increases in Net Foreign Assets and government expenditure lead to a depreciation of the Saudi RER, while GDP growth and gross capital formation result in an appreciation of the Saudi RER in the long run. In particular, a 10 percent rise in NFA tends to depreciate RER by about 0.9 percent, while a similar positive shock on government expenditure leads to a depreciation of the Saudi equilibrium RER by about 4.4 percent. On the other hand an increase of $10 \%$ in Saudi GDP will cause an appreciation of $0.54 \%$ in RER, with a similar increase in capital formation causing a much higher appreciation of the Saudi equilibrium RER to well over 12.4 percent. As shown in table (3), the error correction term is negative (-0.01) and significant. This can be interpreted as meaning that if the actual real exchange rate is above equilibrium, it will tend to fall back to equilibrium and vice versa. Any disparity from long -run equilibrium will tend to be eliminated a'la this dynamic error correction model. As for short- run adjustments, these are almost non-existent except for the government expenditure and RER variables which seem to bear the brunt of the adjustment of real exchange rate towards its equilibrium in the short run. Thus table (3) shows that a rise in RER by 10 percent will likely cause real exchange rate to appreciate by 16.3 percent in the first lag, while causing it to depreciate in the second lag by approximately 7.5 percent each year in the absence of shocks. As for government spending, an increase therein will likely cause an appreciation of the real exchange rate by approximately 9.7 percent in each year in the absence of shocks. Nevertheless, the long-run effect of government spending on equilibrium exchange rate is negative.

\subsection{Saudi RER Misalignment}

As stated earlier, the misalignments of the Saudi riyal will be measured as the spread between the Saudi RER and its equilibrium level. The method of obtaining the equilibrium exchange rate has been fully described earlier on in the methodology section. The evolution of the Saudi RER misalignments over time (1980-2009) is depicted both in Table (4) and figure (1). In general terms, the actual real exchange rate fell short of the equilibrium level by $25 \%$, $16 \%$ and $7 \%$ percent in the years 1980,1981 and 1982 respectively. This, of course, meant an overvaluation of the Saudi riyal. Following 1983, the Saudi real exchange rate rose above the equilibrium real exchange rate thus starting a period of undervaluation that lasted until the year 2009. The downward slide began in 1983 when the real exchange rate fell below equilibrium by $1 \%$ with the declining trend deteriorating further to as low as $10 \%$ in 1984 , $27 \%$ in 1986 and so on until it hit an all-time low of $84 \%$ below estimated equilibrium in 2006 . Thereafter, the decline started a gradual reversal process with the misalignment below exchange rate equilibrium improving somewhat to about 80 percent in 2009. 
Table 4. Saudi RER Misalignment

\begin{tabular}{|c|c|c|c|c|}
\hline year & RER & ERER & misalignment & $\begin{array}{c}\text { Saudi Riyal } \\
\text { Over valued (+) } \\
\text { Under valued (-) }\end{array}$ \\
\hline 1980 & 1.555256 & 2.091189 & 0.256282 & + \\
\hline 1981 & 1.682884 & 2.024063 & 0.168561 & + \\
\hline 1982 & 1.810285 & 1.961073 & 0.07689 & + \\
\hline 1983 & 1.937068 & 1.907846 & -0.01532 & - \\
\hline 1984 & 2.062539 & 1.864724 & -0.10608 & - \\
\hline 1985 & 2.185077 & 1.831912 & -0.19278 & - \\
\hline 1986 & 2.302377 & 1.812117 & -0.27055 & - \\
\hline 1987 & 2.41218 & 1.804896 & -0.33646 & - \\
\hline 1988 & 2.512799 & 1.81042 & -0.38796 & - \\
\hline 1989 & 2.603572 & 1.823458 & -0.42782 & - \\
\hline 1990 & 2.684647 & 1.841844 & -0.45759 & - \\
\hline 1991 & 2.757046 & 1.861439 & -0.48114 & - \\
\hline 1992 & 2.822726 & 1.877871 & -0.50315 & - \\
\hline 1993 & 2.883674 & 1.889217 & -0.52639 & - \\
\hline 1994 & 2.942112 & 1.895919 & -0.55181 & - \\
\hline 1995 & 3.00045 & 1.899887 & -0.57928 & - \\
\hline 1996 & 3.060917 & 1.902555 & -0.60885 & - \\
\hline 1997 & 3.124723 & 1.90474 & -0.6405 & - \\
\hline 1998 & 3.191964 & 1.90694 & -0.67387 & - \\
\hline 1999 & 3.261679 & 1.9087 & -0.70885 & - \\
\hline 2000 & 3.331747 & 1.911086 & -0.74338 & - \\
\hline 2001 & 3.399288 & 1.914799 & -0.77527 & - \\
\hline 2002 & 3.461416 & 1.921249 & -0.80165 & - \\
\hline 2003 & 3.515885 & 1.930047 & -0.82166 & - \\
\hline 2004 & 3.560936 & 1.939508 & -0.836 & - \\
\hline 2005 & 3.595333 & 1.950775 & -0.84303 & - \\
\hline 2006 & 3.618746 & 1.96433 & -0.84223 & - \\
\hline 2007 & 3.632396 & 1.980816 & -0.83379 & - \\
\hline 2008 & 3.63918 & 1.999342 & -0.82019 & - \\
\hline 2009 & 3.643066 & 2.018351 & -0.80497 & - \\
\hline
\end{tabular}

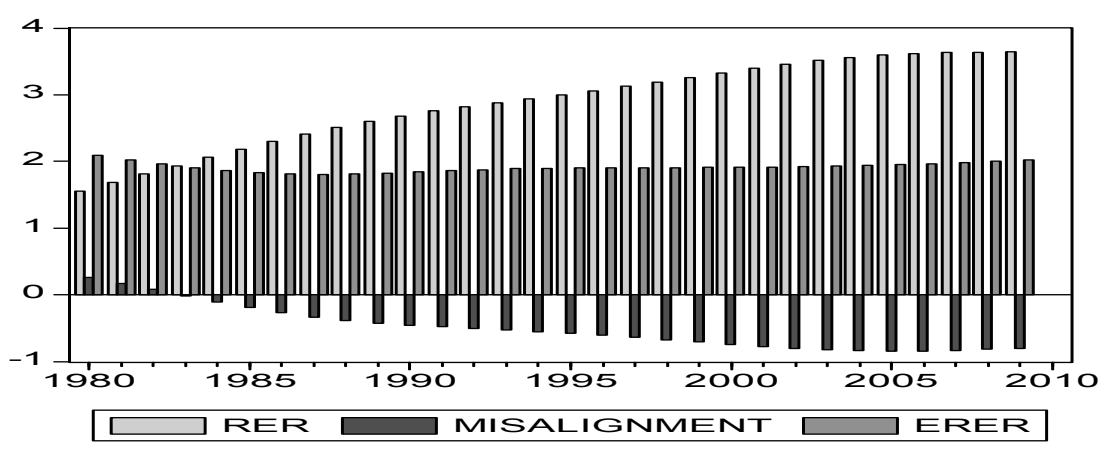

Figure 1. Presents the evolution of Saudi RER misalignment

\section{Conclusion}

The focus of this study was to measure misalignments between the real exchange rate of the Saudi riyal and its long run equilibrium value. By postulating a model of real equilibrium exchange rate determination and testing for a cointegrated long run relationship, it was found that Net Foreign Assets, government expenditure, GDP growth 
and capital formation are the major determinants or explanatory variables underlying real equilibrium exchange rate movements. Thus a long run equilibrium time path for real exchange rate is estimated using the behavioral approach to the determination of the exchange rate. The systematic relationship between the actual exchange rate and the estimated equilibrium exchange rate is used to estimate misalignments between the real exchange rate and its long-run equilibrium. The empirical results of this study indicate that there have been misalignments of the real exchange rate in Saudi Arabia. Based on the estimated model, it can be seen that changes in government spending could act as the major force for the adjustment of the Saudi riyal in the near future. The findings point to the fact that currently, the Saudi riyal has depreciated more compared to the early 1990s or late 1980s.

\section{References}

Afridi, U. (1995). Determining real exchange rates. The Pakistan Development Review, 34(3), 263-276.

Alberola, E. (2003). Misalignment, liabilities dollarization and exchange rate adjustment in LatinAmerica. Banco de Espaă, 0309.

Aleisa, A., \& Dibooglu, S. (2002). Sources of Real Exchange Rate Movements in Saudi Arabia. Journal of Economics and Finance, 26(1), 101-110. http://dx.doi.org/10.1007/BF02744455

Baffes, J., Elbadawi, I., \& O'Connell, S. (1997). Single-Equation Estimation of the Equilibrium Real Exchange Rate.

Cristina, T., \& Valladares, F. (2003). Real Exchange Rate Misalignments. Economics Working Papers (Ensaios Economicos da EPGE, 493) Graduate School of Economics, Getulio Vargas Foundation, Brazil.

Edwards, S. (1987). Exchange Rate Misalignment in Developing Countries. NBER, Discussion paper Number $442,1-52$.

Elbadawi, I. A. (1994). Estimating long-run equilibrium real exchange rates. In J. Williamson (Ed.), Estimating equilibrium exchange rates. Washington, DC: Institute for International Economics, 93-133.

Engel, C., Mark, N., \& West, K. (2007).Exchange Rate Models Are Not as Bad as You Think. NBER Working Paper, No. 13318.

Engle, R., \& Granger, C. (1987). Cointegration and Error-Correction: Representation, Estimation, and Testing. Econometrica, 55, 251-276. http://dx.doi.org/10.2307/1913236

Hodrick, J. R., \& Prescott, E. C. (1997). Postwar U.S. Business Cycles: An Empirical Investigation. Journal of Money, Credit and Banking, 29(1), 1-16. http://dx.doi.org/10.2307/2953682

Mamta, B. (1999). The Determinants of Real Exchange Rate: Theory and Evidence from Papua Guinea.Asia Pacific School of Economics and Management. Working Paper, 2-99.

Rogoff, K. (1996). The Purchasing Power Parity Puzzle.Journal of Economic Literature, 34(2), 647-668.

Sidek, N., \& Mohmmed, Y. (2009). An Empirical Analysis of Malaysian Ringgit Equilibrium Exchange Rate and Misalignment. Global Economy \& Finance Journal, 2(2), 104-126.

Zakaria, M. (2010). Exchang Rate Misalignment and Economic Growth: Evidence from Pakistan's Recent Float. Singapore Economic Review, 55(3), 471-489. http://dx.doi.org/10.1142/S0217590810003857

\section{Notes}

Note 1. From the (HP) perspective, time series are seen as made up of transitory and permanent components. Consequently the permanent components are distilled by minimizing the sum of squares of the second difference.

Note 2 . RER $=\mathrm{e}(\mathrm{p} * / \mathrm{p})$ where e Saudi nominal exchange rate, $\mathrm{p}^{*}$ is USA consumer price index $2005=100 \%$ and $\mathrm{p}$ is Saudi consumer price index $2005=100 \%$.

Note 3 . Where u $\mathrm{t} \sim(0, \sigma 2)$ 